\title{
A Magyar Nyelvstratégiai Intézet reflexiói A magyar nyelv jelene és jövője című kötetre
}

Általános vélemény. A címben a jelen és jövő kiemelése és összekapcsolása arra utal, hogy a kötet a mai magyar nyelv állapotának rajza mellett a magyar nyelv tervezési, stratégiai kérdéseivel is foglalkozik. A mü megjelentetésének szükségességéről, tartalmának és megformálásának módjáról és a munka céljáról az Akadémia elnökének előszava tájékoztat bennünket. Megtudjuk, hogy az Akadémia a magyar nyelvvel való törődést ma is ugyanolyan fontos kötelességének tartja, mint amennyire azt az alapító törvény 1827-ben megfogalmazta. Ez azért is megnyugtató, mert ezzel egyértelmúvé vált, hogy a nyelvstratégia tudományosan megalapozott terület, amelynek a létjogosultságát a legfőbb tudományos testület is elismeri. Másrészt azért is lényeges ez a kijelentés, mert a nemzetközivé váló tudományos környezetben az Akadémia a magyar nyelv mellett teszi le a voksát, a tudományok magyar nyelvü mủvelése ma is kiemelt cél. Ez a Magyar Nyelvstratégiai Intézet (a továbbiakban: MANYSI) egyik stratégiai kiindulópontja is.

Az elmúlt három évtized kutatásaiból kiindulva, azokat összefoglalva igyekszik ez a kötet összegző stratégiai áttekintést adni. Felvázolja a magyar nyelv változásainak irányait és az újabb jelenségeket, abból a célból, hogy a magyar nyelv müvelése, megismertetése és jövőjének formálása szempontjából legfontosabb tanulságokat és javaslatokat a döntéshozók figyelmébe ajánlhassa, például a nyelvstratégia, illetőleg az anyanyelvi oktatás vagy a közigazgatás müködésével kapcsolatban. A fó cél a közösség jólléte, a kultúra fenntartása, a nemzet teljesítöképességének megtartása és fokozása. A kötet a legutóbbi évtizedekben, kiemelten a rendszerváltozás után a magyar nyelvhasználatban és a magyar nyelvben bekövetkezett változásokról szól; a nyelvközösség és a társadalom átalakulásának kérdéseit a nyelvi mozgásokkal szoros összhangban és kölcsönhatásukban elemzi, miközben bemutatja a folyamatok történeti előzményeit is. Igyekszik továbbá a nyelv és a nyelvközösség egészét befogni a vizsgálatokba.

Az Előszó kiemeli a kötet összképre törekvő, illetve szintézis jellegét, az adatok és a magyarázatok fontosságát, a szigorú és pontos tudományos megközelítés követelményét. A tanulmányokra jellemző ,a szabatosság, a megértés és megértetés szándéka, amelyet a józanság és egyúttal az elkötelezettség vezérel" (16).

Minden fejezetben megtaláljuk az elméleti, nyelvtudományi alapozásra utaló kifejezéseket, e kategóriák egymáshoz igazodó megjelenítését. Ennek ellenére, részben a szerzők eltérő tudományterületi szemléletmódja, részben pedig a kutatások korábbi egyéni megalapozása-megtervezése és célzottsága miatt a tárgyalásmód és a nézőpont egysége nem mindig valósul meg; a kötetet a látható logikai egymásra épülés, a tudatos szerkesztés ellenére is leginkább a megjelölt téma köré csoportosított tanulmányok gyüjteményének tekinthetjük.

\footnotetext{
* Szerkesztette Tolcsvai NAGY GÁBOR. Gondolat, Budapest, 2017. 513 lap.
} 
A TOLCSVAI NAGY GÁBOR által felvázolt elméleti keret, az alapmegközelítés funkcionalista, kognitivista. Ez mindenképp hasznos, hiszen a nyelvstratégia operatív, gyakorlati, és a nyelvnek ezt az oldalát - az imént említettel ellentétben - a legtöbb nyelvészeti irányzat képtelen megragadni. A funkcionalista megközelítés a nyelvet (ahogyan nevében is áll) funkciójában, a társadalmi életben betöltött szerepében vizsgálja, és a kultúra részének tartja. További előnye ennek a szemléletnek az is, hogy állást foglal. A legtöbb tudomány, tudományos irányzat nem meri ezt megtenni, mivel úgy tartja, hogy az sértené (kvázi) objektivitását. Ám az ellentmondás éppen abban rejlik, hogy például az érzelmeket érzelem nélkül, az értékeket értékítélet nélkül képviselni nem lehet, márpedig a humán tudományoknak igenis feladatuk az értékszempont figyelembevétele. Így tehát a funkcionalista nyelvészet, amely a nyelv társadalmi, társadalomalakító szerepét vizsgálja, nem marad semleges, nem távolítja el magát, hanem kijelenti, hogy a két véglet közötti egyensúlyi állapotot tartja ideálisnak. Természetesen a „valódi közép” megtalálása nem könnyü feladat, mivel annak elhelyezkedése mindig viszonylagos.

Ez a megközelítés támogathatja és megalapozhatja a készülő nyelvstratégiát, jóllehet egy stratégia szövegében nem kell közvetlenül megjelennie minden általános és elméleti megfontolásnak. Véleményünk szerint a nyelvstratégiának tudományos és szakmai alapvetésből kiindulva, a problémák feltárása után azok megoldására vonatkozó cselekvési tervet kell tartalmaznia; fel kell sorolnia a tennivalókat, az intézkedési javaslatokat, az ehhez szükséges intézményrendszert, az anyagi forrásokat és az ellenőrzés folyamatát.

I. A jelen tapasztalati tere: nyelv és nyelvközösség (TOLCSVAI NAGY GÁBOR). Az első fejezet a magyar nyelv és nyelvközösség ezredfordulós és várható jövőbeli helyzetéről kíván összefoglalást adni. A vizsgálat indokoltságát elsősorban az adja, hogy az elmúlt 30-40 esztendő olyan jelentős változásokat hozott közösségünk, társadalmunk, gazdaságunk, kultúránk és nyelvünk életében, amely szükségessé teszi egy tudományos szintézis létrehozását ahhoz, hogy nyelvünk jelen állapotát és jövőbeli lehetőségeit leírhassuk. A szintézis jelentőségét megalapozza, hogy a közelmúlt folyamatait elemző, értelmező, többnyire empirikus kutatásokon, sőt szakmai-tudományos konszenzuson alapul, amelynek hitelességét az MTA I. osztálya mint tudományos testület erősíti meg. Érdemes megjegyeznünk azt is, hogy mindez együtt jár - a nyelv komplex és dinamikus értelmezésén kívül annak a tudományos alapú kinyilvánításával is, hogy a nyelvvel, a nyelvhasználattal kapcsolatos (irányított) tevékenységre s z ü k s é g 1 e h e t - a magyar nyelvközösség esetében viszont s z ü ks ég van. Így lehetséges, hogy a munka, amely „Egyszerre érvényesíti a tárgytudományos leírást és a közösség önalkotásának folyamatát" (21), alapul szolgálhat a további cselekvéshez, leginkább egy szaktudományosan megalapozott, lényeglátó nyelvstratégia kidolgozásához, amely további, a nyelvvel, illetve nyelvhasználattal kapcsolatos cselekvések programja lehet.

Az alapvetésből az is kiderül, hogy a helyzetleírás nem tisztán nyelvtudományi jellegü és szemléletű, hiszen a történetiség, a nyelv és a beszélőközösség együttes leírása, valamint a jövőbe tekintés, a stratégiai cselekvésre irányuló és az azt ösztönző célzatosság megkívánja a komplex megközelítést. A cél az ellentétesnek 
látszó hatások dinamikus egyensúlyozásával egy versenyképes, stabil, mozgásában és változásában önazonosságát megtartó közösség és nyelv fenntartása, folyamatos teremtése és müködtetése. E gondolat a záró fejezetekben a stratégiai cselekvés céljai között ismét visszatér, és több fejezetben is hangsúlyossá válik.

A nyelv és a nyelvközösség egymást feltételezik, az ember biológiailag képes beszélni, de a nyelv alkotó használatát csak az interakciókban tudja elsajátítani, gyakorolni, fejleszteni. Az elemi interakciók pedig a közösségben formálódnak a közösség számára értelmezhető nyelvi formákká: „A nyelvi tevékenység nem csupán két beszélőtárs ügye, a közösségképzés lényeges elem: a nyelvi cselekvés és a megismerés dialogikus megnyilvánulásai közösséget képeznek" (23-24). A nyelvközösség kommunikációs rendszere folyamatosan alakul, de a közösség maga normák szerint szabályozza is, elsősorban a helyzetnek való megfelelőség szerint.

A nyelv kulturális, ideológiai értelmezései címü fejezet azért kiemelkedően fontos, mert tárgyilagos nézőpontból igyekszik értelmezni és értékelni az egyes, ideológiákba hajló, azokkal keveredő nyelvmegítéléseket: a nyelvi múködés szempontjából igen fontos standard változatnak és a helyesség kategóriájának vitájában folytonosan összecsapó és kibékíthetetlen ellentétet mutató vélemények és csoportosulások objektív nézőpontból, mintegy felülnézetből kapják meg kritikai értékelésüket. Fontos megállapítás, hogy az ideológiákat képviselő, olykor szinte erőltető megnyilvánulások maguk is egyértelműen és egyoldalúan ideológiai alapokon állnak, onnan támadnak vagy vitáznak (vö. az aszimmetrikus fogalmi meghatározottság kategóriával). Az összegzésben - megnyugtató módon - azt olvashatjuk, s mélyen egyetérthetünk a szerzővel, hogy a nyelv, s így természetesen a magyar nyelv vizsgálatakor sem lehet teljesen elkülöníteni a tudományos és a nem tudományos, racionális és feltételezett, az értékelés nélküli és az értékelő szempontot is tartalmazó megközelítéseket, mivel az érték, a kultúra, valamint a közösség történelmének figyelembevétele nyitott szemléletet követel meg. És bár a hierarchikus társadalmi viszonyok értelmezésével így eredményesebbek lehetünk a nyelv helyzetének leírásában, kutatásában, még mindig nem gondolhatjuk, hogy eleget tudunk - s a komplex emberi nézöpontot és az önreflexiót ekkor sem kapcsolhatjuk ki, hiszen nem lehetünk mindentudók, nem gondolhatjuk, hogy azokká váltunk. A nyelvstratégiában mindennek különös jelentősége lesz majd. Megkönnyítheti például azoknak a vitáknak a lefolytatását, amelyek eddig a nyelvmüvelés, a nyelvi tervezés, a nyelvstratégia teljes egészét a nyelvtudomány hatókörébe szerették volna vonni, illetőleg amelyek a nyelvtudomány hatókörét és illetékességét a stratégia egészére kizárólagosan ki akarták terjeszteni.

\section{A magyar nyelv és nyelvközösség helyzete szűkebb és tágabb kör-} nyezetében (TOLCSVAI NAGY GÁBOR, ANDRÁSSY GYÖRGY, GYÁNI GÁBOR). A szerző-szerkesztő objektív álláspontot foglal el, elhatárolja a magyar beszélőközösség, a nemzet és az állam fogalmát; kijelenti, hogy ezek történeti koronként egymást átfedő kategóriák (50). Egyet lehet érteni azzal, hogy a magyar nyelv és nyelvközösség a régió más etnikumaival és nyelveivel kapcsolatban áll, így a régió nyelveinek, kultúráinak, etnikumainak az áttekintése fontos a magyar nyelvközösség ezredforduló utáni helyzetének leírásához és értelmezéséhez (49). Ez az elkép- 
zelés egybeesik a MANYSI-nak azzal az álláspontjával, hogy nyelvünk fennmaradása leginkább a határon túli beszélőközösségek körében van veszélyben, így ezeknek a magyar beszélöközösségeknek a fennmaradására csak a régió nyelveinek, kultúráinak, nemzeteinek a tanulmányozásával lehet stratégiát alkotni. Intézetünk stratégiai célja a környező országok magyarlakta területein müködő nyelvtudományi mühelyek, oktatási és kutatási központok támogatása, munkájuknak az ösztönzése, hisz éppen ezek az intézmények és közösségek tudnak tudományos alapot nyújtani a kisebbségi helyzetben lévő magyar nyelvközösségek fennmaradását célzó stratégiának.

A magyar nyelv és nyelvközösség Európában címú fejezet szerzője tárgybeli ismertetését a történettudományi modellek (ezek közül is részletesebben KOSÁRY DOMOKOS, valamint SzÜCS JENÖ koncepciójának) bemutatásával kezdi. A térség - magyar nyelvet is érintő - nyelvtudományi modelljeire rátérve kiemeli a BALÁZS JÁNOS, majd DÉCSY GYULA munkáin alapuló areális modellt, melynek lényege a dunai nyelvszövetség, amelybe a magyaron kívül más nyelvek is beletartoznak. Azt is megemlíti, hogy ezek a nyelvek milyen nyelvi szinteken, milyen nyelvi jegyekben hatottak egymásra (54-55). Bár egyesek érthetetlen módon - vitatják, nyilvánvaló, hogy nemcsak a magyar vett át idegen elemeket, hanem a környező nyelvek is vettek át a magyarra jellemző vonásokat. További összegző, részletező kutatásokra van szükség ahhoz, hogy pontosabban lássuk a magyar nyelv kontaktusjelenségeit a dunai nyelvszövetségben. - A szerző röviden kitér a legfrissebb politikai, ideológiai változásokra is, és az a konklúziója, hogy régiónk átmenetet képez Kelet és Nyugat között, de mindvégig megtartja a nyugati orientációt, és a pluralizmus velejárójaként a szovjet koloniális időszak eltelte után egyszerre mutat állandóságot és változik viszonylag gyorsan (60).

Igen fontos, hogy az Európai Unió számon tartja a tagállamok hivatalos nyelveit, hogy a nyelvi jogok köre tág ugyan, de a kisebbségi közösségek kollektív jogai korlátozottak, így nem tudja megakadályozni például „a Magyarországgal szomszédos államok kisebbségeinek nyelvi jogfosztását" (60). Bár a megfogalmazás általános, távolságtartó, lényegét tekintve igaz. - Azt az állítást is támogatni lehet, hogy az Unió alapértékének számít a tőke, a munkaerő és a szolgáltatások szabad áramlása, és az így alakuló interkulturális hatások megváltoztatják az európai nyelveket, beszélőket, sőt, az identitást is. Ennek következtében egyszerre jelentkezik az igény a többnyelvűségre és az összetett kulturális önazonosságra, valamint az élesen körülhatárolódó, egyféle identitásra (60). A szerző kijelenti, hogy nem igazolódtak az interkulturális hatásokból levezetett elméletek, amelyek szerint gazdasági, politikai és kulturális szempontból sem észszerủ a kisebb európai nyelvek fennmaradása, és inkább ezek összeolvadása várható (60-61). Ám hozzáteszi, hogy az uniós térben a magyar nyelv közepes méretü nyelv, jelentős súlya van, az unió egyik hivatalos nyelve, $\mathrm{s}$ ez bizonyos mértékü védettséget ad. Az is igaz, hogy az unió elsősorban inkább az egyéni szabadságot védi, és nem a kisebbségekét; emiatt a határon túli magyar kisebbségek nyelvi jogainak diszkriminációja is fennáll az EU-n belül (61). Ez véleményünk szerint fontos állítás, hiszen a helyzet megváltoztatása, a határon túli magyar kisebbségek nyelvi fennmaradásának biztosítása a legfontosabb nyelvstratégiai célok egyike. 
A magyar nyelv és a magyar nyelvközösség jogi helyz e te fejezetének bevezetésében a szerző részletesen kitér a nyelvi jogok definíciójára. Kiemeli, hogy a nyelvjog nem korlátozódik az államok belső jogára, létezik nemzetközi nyelvjog is. Nehézséget jelent azonban, hogy nincsen egyetemesen elfogadott értelmezése ennek a terminusnak (tudniillik a nyelvi jogoknak).

A tanulmány rövid történeti áttekintést ad a magyarországi nyelvjogokról, a honfoglalás korától egészen a jelenkorig. Bár kitér Trianon földrajzi, politikai, nemzeti, jogi következményeire, meglehetősen szüken szól róla; pedig ezt a kérdéskört jogi, szociolingvisztikai és társadalomtudományi szempontból mélyebben is érdemes lenne elemezni (legalábbis bizonyos szintig, régiókra lebontva), hiszen ez az egyik fő oka a nyelvi jogok határon túli csorbulásának. A tanulmány általános szempontrendszere mellett szükség lett volna (akár egy másik tanulmány keretében) részletesebb, a határon túli területekre lebontott nyelvjogi elemzésekre is.

A nyelvi jogokkal kapcsolatban a szerző kitér arra, hogy a nem megfelelö, pontatlan megfogalmazás milyen ,szabad” jogértelmezéseknek ad teret, s hogy ezáltal sokszor nem az eredeti jogszándék érvényesül. Kiváltképp fontos ez a megközelítés a MANYSI-nak, két szempontból is. Egyrészt nyelvi jogi (nyelvpolitikai) vonatkozása miatt problémafeltárást jelent: tulajdonképpen azonosítja az egyik lehetséges okát annak, hogy az uniónak miért nincs még átfogó, konkrét kisebbségi, őshonos nyelveket védő jogszabályi „csomagja” (itt említendő meg egy polgári kezdeményezés, a „Minority SafePack”, amely éppen ezt igyekszik pótolni). Másrészt felhívja a figyelmet egy szintén általánosnak mondható, leginkább nyelvi természetü problémakörre: a jogszabályok megfogalmazásának szándékos vagy szándéktalan pontatlanságára.

A szerző a hivatalos nyelvek problémáját jogelméleti szempontból tárgyalja, és elgondolkodtató következtetésekre jut. Így például arra, hogy a hivatalos nyelvek meghatározásakor figyelembe kell venni a földrajziság, a „hely” kérdését. Jogi szempontból tehát minden nyelvnek hivatalos nyelvnek kellene lennie abban az országban, ahol az öshonos, és így a közigazgatásban, a bíróságokon, az oktatásban, a közéletben is teljes körúen kellene tudnia használni azt az őshonos beszélőnek. Az összes szomszédos ország ebbe a kategóriába tartozik, így alapvető emberi jog lenne, hogy mindegyikben hivatalos nyelv legyen a magyar, és a szerző ezt - nagyon helyesen - nem is tartja lehetetlen küldetésnek, ám stratégiai megközelítésre, összehangoltságra van szükség.

ANyelvközösség, nemzet, állam, társadalom viszonya alfejezet történeti megközelítésből tárgyalja első lépésben a dualista Magyarország oktatáspolitikai törekvésein keresztül az akkulturáció, a nyelvi egységesülés/ egységesítés kísérleteinek hazai nemzetiségekre gyakorolt hatását, annak eredményességét. Nagy erénye e résznek, hogy a szerző elhelyezi az 1867 és 1918 közötti magyar nemzetiségpolitikát a korabeli nemzetközi inerciarendszerben, $\mathrm{s}$ megállapítja, hogy az „egyáltalán nem mondható túl szigorúnak vagy különösen elnyomónak: a francia, az angol, a német vagy a spanyol politikai gyakorlatnál, melyek mind a restriktív irányt erősítik, koncesszív, olykor disztributív mivoltával inkább a liberálisabb európai minták körébe sorolandó" (97). Ezt követően a szerző a Trianon utáni gyökeresen megváltozott közeget, a kisebbségbe került ma- 
gyar közösségek identitás- és nyelvhasználatbeli dilemmáit egy esettanulmányon, a csehszlovák állam és a felvidéki-kárpátaljai magyar kisebbség viszonyának történetén keresztül érzékelteti. Ilyen informatív és a témában még manapság is felfelbukkanó sematikus megközelítéstől elszakadó ismertetést szívesen fogadna az olvasó román és délszláv viszonylatban is.

III. A magyar nyelvközösség belső szerkezete és müködése a Kárpátmedencében (TÓTH PÁl PÉTER, TOLCSVAI NAGY GÁBOR, PÉNTEK JÁNOS, KISS JENÖ, KNIPF ERZSÉBET, BÁBA SZILVIA). A Kárpát-medencei magyar nyelvközösség belső szerkezetével és müködésével foglalkozó fejezet alapvető törvényszerüségei nyilvánvalóak, világos alapvetést adnak. A jövőre nézve legfontosabb teendők abból a megállapításból következnek, hogy a népességfogyást felgyorsítja és visszafordíthatatlanná teszi a határon kívüli magyarságnak az anyaországba való beköltözése; ezzel együtt azonban arra is figyelmeztet a szerző, hogy nem elegendő a Magyarországon zajló folyamatokat figyelembe venni az egész magyar nyelvközösség sorsa szempontjából. Ez a megállapítás is erősíti azt a fentebb már kifejtett álláspontot, hogy a MANYSI jó úton jár, ha az egyik leglényegesebb stratégiai feladatnak a határon túli magyarság fennmaradását célzó intézkedések kidolgozását tartja.

A magyar nyelvközösség kommunikációs rendszere 1945 u tá n címü fejezetben a rendszerváltozás előtti és utáni időszak főbb tényezői mellett az ún. közösségi szemantika változásairól is szó esik: a természetes, eredeti jelentésképzés egyes mozzanatait példa szemlélteti (a polgármester, tanácselnök jelentése az értelmező szótárak korábbi és újabb kiadásai alapján). 1990 után a szerző szerint ún. heterarchikus rendszer jelent meg: nyilvános beszélgetések, társas viszonyok, tagolt nyilvánosság jellemzik ezt az újabb időszakot. Az új rendszer hálózatossága, többértékủsége, bonyolultsága világossá és nyílttá vált, $\mathrm{s}$ az ezredfordulóra már dinamikus és nyitott rendszerként írhatjuk le a magyar nyelvközösség hálózatát, mely folyamatos változásban van. Fö tényezői a nyitottság, az újítás, a bárki számára hozzáférhető diszkurzusok, társalgásrendek és -rendszerek. Az önalkotó jelleg szembetünő az ezredforduló közlésrendszerében: nincs cenzúra, nincs külső ideológiai ellenőrzés, a társalgásokat a résztvevőktől származó saját szabályszerüségek irányítják, folytonos újításokkal és egyéni interakciókban alakul és változik a nyelv. A rendszer nyitottá válik újonnan belépő beszédpartnerek számára, új közösségek és közlésformák, alrendszerek számára, új közlési, illetve nyelvi konstruálási, szerkesztési módokra; nagy az igény az önreflexióra, önértelmezésre. A politika helyére azonban másfajta cenzúra kezd belépni: az üzleti, korporációs korlátozás, a társadalmi-közösségi alapú cenzúra, a verbális erőszak, a politikailag korrekt beszédmód sablonjai; állandó élő jelenléttel a média és a világhálós csatornák, rendszerek belépnek a magántérbe, újabb kényszerítő hatásokat hozva létre. Az internet egyszerre korlátlan és más módon korlátozó, kényszerítő, deformáló, ellenőrző stb. A közlés gyorsabb, célratörö, összpontosító, hatékony, takarékos.

Az adekvátság is megjelenik a felsorolásban, ez azonban erősen vitatható. Épp az adekvátság átalakulása, a normahiány, a normalazulás miatt válik kérdé- 
sessé az adekvátság, illetőleg az inadekvátság veszi át a helyét mind gyakrabban a stiláris, szerepbeli és udvariassági kötelmek tekintetében. Említi is a szerző a bizalmasságot, az udvariasság területén a tekintélyi formák helyébe lépő lazább, közvetlenebb megoldások terjedését, a bizonytalanságokat. Kitér még a szintén lényeges újabb egyenlőtlenségek megszületésére: a korcsoportokat, társadalmi csoportokat és különféle egyéb csoportokat eltérően érintették a változások. A média, az internet elterjedése és térnyerése főleg az idősebbeket hozta hátrányos helyzetbe, a fiatalok pedig jelentős előny(ök)höz jutottak. A MANYSI szerint a norma, a viszonyítási pontok változásának tudatosítása, a kommunikációs technológiák megismertetése, az ezzel együtt járó képességek és kompetenciák kialakítása fontos stratégiai cél; megvalósulásához hozzájárulhatna, ha a fenti összefüggést a tudomány képes lenne közérthető módon eljuttatni a magyar beszélőközösséghez. A közérthetőség, a kérdésfelvetések nyilvánossága, az érdemi tudományos vita alapvetően fontos ahhoz, hogy a társadalmi kommunikáció, az információtechnológia, a gazdasági környezet átalakulásával együtt módosuló társadalmi kommunikáció minél zökkenőmentesebb legyen. Mindennek a legmegfelelőbb színtere pedig az iskola lenne. Így kapcsolódik össze a tudományos alapvetés, a tudományos ismeretterjesztés és az oktatás, nevelés.

Az anyaország és a külső régiók viszonyára vonatkozóan fontos és helytálló az a megállapítás, hogy a közlési rendszer történelmi szétszabdalásának és részekre bomlásának ellenére, majd pedig az emiatt kialakuló elszigetelődés, különfejlődés, sőt az idővel egyre nagyobb arányban bekövetkező beolvasztás és nyelvvesztés ellenére sem vált a magyar nyelv többközpontúvá. Századunk elejére a határon túli magyar anyanyelvü kisebbségek - különböző fokon - kétnyelvüvé váltak. A széttartás, a különfejlődés leginkább a szókincsben mutatkozik meg, föként a hivatalos nyelvhasználat, a közigazgatás, a nevek és a szaknyelvek területén. A MANYSI a tevékenységébe beépítette ezt az összefüggésrendszert, mert a közigazgatási kommunikáció, a névtan és a szaknyelvek kutatási eredményeinek összegyüjtése, az erre vonatkozó álláspontok összegzése, majd az ebből való stratégiaalkotás meghatározó területe az intézet tevékenységének.

Kialakult ugyan a regionális közösségi tudat, az önazonosság, ám a szétdaraboltság ellenére a magyar nyelvközösség lényegében egységes maradt. A határtalanítás a trianoni határokkal létrejött tagolt helyzet meghaladása, afféle nyelvi újraélesztési és újraegyesítési program. Ennek a tervezése bonyolult, mert a természetes módon változatosságot mutató nyelvközösségben a nyelvi tények összevetése, a különbözések és azonosságok leírása, értelmezése csak a saját közlésrendszerükben és szükebb környezetükben betöltött funkciójukból vezethetö le. Fontos tehát, hogy tudjunk a határon kívül és belül használt szókincs eltéréseiről, a meglévő változatokról. A határtalanításban, a kölcsönös megértés és a nyelvközösség egyesítésének munkájában nagy feladat hárul a Termini Kutatóhálózatra, amelynek anyagi támogatására a Nemzetstratégiai Kutatóintézet és a MANYSI is tett lépéseket.

A magyarországi helyzet fejezete a belső nyelvközösség nyelvi helyzetét vázolja az 1990-es rendszerváltozás utáni időszak jellemző mozzanataival. Megemlíti a populáris kultúrára és nyelvváltozatokra épülő új típusú régiókat, 
valamint a nyilvánosságban megjelenő számos újabb stílus és regiszter megjelenését, a közömbös, az informális kifejezésmód felé való elmozdulást. A bulvár, a bizalmasság, a durvaság egyaránt felszínre került, $\mathrm{s}$ megjelent a nyilvános közléstérben is; az alacsonyabb rangú változatok is megszólaltak, az identitás vállalása és a hatáskeltés középpontba került.

Az ezredfordulón a Kárpát-medence magyar nyelvü közlésrendszere sajátos képet mutat; ennek tényezői: a történetileg szerves fejlődés maradványai, a trianoni régiók rendszere, az állandóan változó, mozgékony hálózatok. Igen fontos a fejezet azon megállapítása, hogy a sokféleség zavarok forrása lehet, s hogy a többféle okból jelentkező, egységre való törekvés is szülhet feszültséget.

A fejezet a nyelvi alkotás megvalósulását, a nyelvi változások jellemző sajátosságait a stílus változásában igyekszik bemutatni. A stílus jelentős változásának igényét és folyamatát a városi, populáris kultúra csoportjainak mozgásából és térnyeréséből, illetőleg sajátságaiból látja levezethetőnek a szerző, majd vázolja az e csoportok nyelvi közlésben mutatott viselkedésének meghatározó összetevőit. Végül e jellemzők hatásaként értelmezi és mutatja be a beszélőközösségben általánosan tapasztalható főbb újdonságokat (például pillanatnyiság, hatáskeltés, érzelmi modulációk, elmosódottság, átértékelés-átértelmezés). Az egymástól távol eső forrás- és céltartományok szokatlan összekapcsolásából eredő stíluserő (potenciál) a bizalmas, nem formális beszédmód kiterjesztéséhez vezet, és kapcsolódik a városi-populáris csoportok hálózatban elfoglalt kiemelt helyzetéhez. A helyzet és a nyelvi változások megismertetése lehet a nyelvstratégia célja, mert csak a megalapozott, nem sztereotip tudás alakíthatja ki a nyelvünkhöz való viszonyulás, a nyelvi viselkedésmód jól követhető, stabil rendszerét.

A k ü $1 \mathrm{~s}$ ő régiók helyzetét tárgyaló fejezetben többek között képet kapunk a szórvány és a sziget helyzetü közösségek nyelvleépülésének és nyelvvesztésének folyamatáról; vázlatosan áttekinthetjük a kétnyelvüség és a nyelvcsere, az identitásváltás és az asszimiláció kérdéseit is. A közlésszínterek és regiszterek fogyását és a nyelvi hiányt, térvesztést, a nyelvi kompetencia szükülését említve a szerző a közéleti-szakmai használati szint töredékességére hívja fel figyelmünket, s rámutat, hogy ez is csak tudatos nyelvi tervezéssel hozható helyre (az angol nyelv erejének, hatásának fokozódása, elsődlegessége azonban újabb akadályt jelenthet). A határon túli magyar közösségek nyelvhasználati színtereinek a tervezése kiváltképpen kényes feladat, mert a nyelvtudomány és a politika eltérően értékeli a nyelvvesztéssel járó folyamatokat. A nyelvtudomány számára a funkcionális és a strukturális nyelvvesztés természetes folyamat olyan kétnyelvü helyzetben, ahol nincs vagy nem elégséges a nyelvi kisebbségeket támogató nyelvpolitika. Nem autonóm kisebbség esetében a kiegyensúlyozott kétnyelvüség inkább járható és célravezető út lehet. Az államnyelv magas szintü ismerete ugyanis csökkenti a kiszolgáltatottságot, erősíti az érvényesülés lehetőségét. És ha fennmaradnak az anyanyelv használatának természetes színterei - a családon kívül is -, különösen ha nyelvpolitikai lépések is segítenek fenntartani ezeket a színtereket, akkor lehetőség van az anyanyelv megtartására. Ez viszont már túlnyúlik a határon túli magyar kisebbségek esetében a magyar joghatóság körén, tehát diplomáciai, nemzetközi jogi feladat. 
Bizonytalanul bár, de egy új korszak eljövetelének lehetősége körvonalazódik, melyben egyrészt bővülnek a nyelvhasználati színterek, kitágul a nyelv hatóköre, nő a standard és az angol nyelv szerepe, s a világhálón megvalósuló közlések révén újabb elemek lépnek be a nyelvet befolyásoló tényezők sorába. Mindezek olyan folyamatok, amelyekre az oktatásnak fel kell készülnie, amelyeknek be kell épülnie a tananyagfejlesztési stratégiába, a pedagógusképzésbe. A MANYSI erejéhez mérten közremüködik e tevékenységekben, de legalábbis figyelemmel kíséri a központi tananyagfejlesztést, a tantervi fejlesztéseket, és ugyanez volna kívánatos a közigazgatás és a központi fejlesztők részéről is.

A nyelvjárások címü fejezet - a területi változatnak mint az egyik meghatározó teljes nyelvváltozatnak a körüljárása, általános jellemzése és használati tereinek, megjelenéseinek vázolása után - a magyar nyelvjárástípusokat és a mai nyelvjárási állapotot tekinti át. A kötet témája szempontjából különösen fontos a nyelvjárásváltozás okainak és tényezőinek, lezajlásának alaposabb tárgyalása. A szerző szerint a változások nyomán nem kell a nyelvjárások eltünésétől tartanunk, csupán a nyelvjárási jelenségek kopásával, funkcionális átrendeződésével kell számolnunk. Továbbélésük azonban függ a használatukhoz füződő attitüdtől és presztízstöl. A megoldási javaslatokról ugyan nem olvashattunk, de az is nyilvánvalóvá válik, hogy szükség van a nyelvjárásokra vonatkozó stratégiai lépések kidolgozására. A nyelvjárások megbélyegzettségét csökkenthetné, esetleg meg is szüntethetné a megfelelő iskolai oktatás és a tudományos ismeretterjesztés, valamint a nyelvjárásoknak a médiában való rendszeres, tervszerü és helyénvaló megjelenése, megjelenítése is (elfogadva azt az álláspontot, hogy a nyelvjárások országos médiában való általános használata a valóságtól idegen olyan nyelv esetében, amelynek van központi változata, és vannak helyi [regionális] változatai).

A magyar standard helyzete címü fejezetben a nyelv tervezése szempontjából lényeges mozzanatként merül föl, hogy a standardizációnak mint folyamatnak is figyelmet kell kapnia (nemcsak a kodifikált, kész rendszernek). A nyelvstratégia szempontjából különösen fontos megállapítás, hogy az 1990 utáni időszakban a standardizáció, a kodifikáció intézményes jellege csökkent, s hogy maga a standard és a mintaváltozat funkciója is elbizonytalanodott. Mindebből az is következik, hogy a nyelvstratégia kimunkálásakor a standard szerepét erősítő és gyengítő tényezőket egyaránt számba kell vennünk, s hogy a standard jelentőségének és norma jellegének körüljárása, majd pedig az ebből fakadó kulcsteendők meghatározása a nyelvstratégia számára alapvető feladat.

$\mathrm{Az}$ öshonos, nem magyar nyelvü kisebbségek helyzetét tárgyaló fejezet a nyelvcsere, a nyelvváltás jelenlegi állapotáról egy kisebbségi nyelvcsoportokra (német, beás, román, szlovák, roma, szerb) vonatkozó, 2001 és 2004 között végzett többdimenziós kutatás eredményeinek alapján tájékoztat. A vizsgálat a nyelvcsere helyzetét mutatja jellemző állapotnak: ez tekinthető a mára vonatkozóan jellemzőnek és érvényesnek a többi nemzetiség esetében is. A nyelvstratégiai irány összhangban van a fejezet megállapításaival, tudniillik hogy az oktatás a kulcskérdés, és elsősorban az anyanyelvet oktatók kinevelése, a nemzetiségi tanárképzés helyzetének további javítása látszik a legfontosabb teendőnek. 
A történetileg kialakult diaszpóra-közösségek (USA, Kanada, Latin-Amerika és Ausztrália) esetében a magyar nyelvnek az etnikai hovatartozásban és az önazonosításban van meghatározó szerepe; az egyes nemzedékek magyar nyelvhez való viszonyulása, a nemzeti identitás megőrzése a diaszpórában is ugyanolyan lényeges kérdés, mint a Kárpát-medencében. A szerző igen fontosnak tartja a nyelvi örökség megtartását, ápolását, és ezt közös felelősségként, közös feladatként jelöli meg a jövőre nézve. E feladat csak a magyartanítás módszertani megújításával vihető véghez hatékonyan. A MANYSI felkutatja a diaszpórában élők és a magyar nyelv iránt érdeklődő nem magyar (származású) közösségek tananyag-fejlesztési és oktatási igényeit, és megtervezi az elvégzendő feladatokat.

A III. nagy fejezetben a Kárpát-medence magyar nyelvközösségének jelenlegi helyzetéről összességében jó áttekintést kapunk: különösen értékes és sikeres az összefoglalás a történeti folyamatok és összefüggések vázolásában, a határon kívüli beszélöközösségek müködésének bemutatásában, valamint a kiemelten fontos nyelvváltozatoknak, nyelvjárásaink és a köznyelvi (standard) mintaváltozat átalakulásának megragadásában, a változások okai és összefüggései társadalmi, történeti meghatározottságának bemutatásában, s különösen ezek elméleti megalapozásában, rendszerezésében. Sajnos kevés gyakorlati útmutatót kaptunk arra nézve, hogy a kedvezőtlen folyamatok miként változtathatók meg.

IV. A nyelvhasználat intézményes színterei (DOMONKOSI ÁGNES, Szabómihály Gizella, PrószÉKy GÁBOr, Kugler NóRA, VANČO IldikÓ). A fejezet elsőként a köszönések, az udvariassági formulák és a megszólítások vizsgálatával foglalkozik kognitív pragmatikai, interakcionális szociolingvisztikai keretben. A nyelvi kapcsolattartási formák egy beszélőközösség kulturális jelzőrendszerét képezik, amelyből megismerhetjük a társadalom változásait. Egy változóban lévő társadalomban általánosak a megszólítási bizonytalanságok, hiszen a társas kapcsolattartási viszonyok is változnak.

DOMONKOSI ÁGNES kiindulópontjai közé tartozik, hogy a tegezés és nemtegezés összefüggést mutat a közösségi szerepekkel és értékekkel. Empirikus adatokra, illetve modellezésből származó adatokra alapozza megállapításait, és tekinti át ezt a stratégiai fontosságú nyelvi területet. Megállapítja, hogy a tegezés terjedése az elmúlt évtizedek leglátványosabb változása. Ezt a megszólítási formát már a nem egyenrangú, de bizalmas viszony kiépítésére is lehet használni. Szintén alapvetö, hogy a státuszbeli, szerepbeli különbségektől és a bizalmi viszonytól függetlenül is általánosnak tekinthető a 40 év alatti korosztály általános tegeződése. Ennek a változásnak az eredményeként a fiatalabb korosztályban megváltozik a tegezés értéke, már a hivatalos helyzetekben is megfelelőnek tartják korosztályi sajátosságként. Az életkori alapú, szolidáris szándékú, nominális formák nélküli tegezés informális, és a nominális formákkal való kombinálása az említett korosztályban a tegezés funkcióját tágítja, átveszi a nemtegező formák számos szerepét. Mindennek terjedése aligha kívánatos: a megoldási javaslat kidolgozása a MANYSI-ban folyamatban van. 
„A hivatalos megszólítási formák napjainkra egyrészt a nyelvi elemkészlet elégtelensége, másrészt a nyelvhasználati bizalmasság kiszélesedése miatt viszonylag szükebb körre szorultak vissza" (290). Ennek ellenére nyilvánvalóan szükség van hivatalos formákra, ám ezen a területen az egyelöre még ellentmondásos megítélésű változatokból fognak kiemelkedni az általánosan elfogadott változatok. Ez a megjegyzés is mutatja a nyelvi tervezés nehézségeit és fontosságát.

A mindvégig leíró szemléletủ elemzés röviden kitér a köszönésformák bemutatására, és megemlíti a legújabban terjedő Szép napot! formát (291). Véleményünk szerint már észlelhető, hogy a napszakokhoz igazodó változatok is terjednek (Szép reggelt!, Szép estét!).

A magyar nyelv használata a közigazgatásban a mag y a r r l s zo m s zéd o s o r s zá g o kb a n címüfejezetszerzője SZABÓMIHÁLY GIZELLA. Igen fontos a közigazgatás nyelvhasználatának leírása, elemzése, hiszen a jogállamiság alapelvéből és az általános etikai elvárásokból is levezethető, hogy fontos nyelvstratégiai cél a közigazgatás és az állampolgár szakszerü, pontos és közérthető kommunikációja. Ezen a téren viszont nemcsak a szomszédos országokban, hanem hazánk intézményeiben is van tennivaló; kár, hogy a kötet nem tartalmazza a hazai közigazgatás nyelvhasználatáról folyó kutatásokat, leginkább az intézetünk 2017-ben elvégzett ez irányú kutatásait, szakmai javaslatait. Erre irányuló kutatások a MANYSI mellett más intézményekben, kutatócsoportokban is zajlanak (például a Nemzeti Közszolgálati Egyetem Közszolgálati Média- és Kommunikációtanulmányok programjában, a Miskolci Egyetem kutatócsoportjában, valamint a Magyar Jogi Nyelv címü folyóirat hasábjain). A MANYSI az NKE kutatási programjával együtt részt vett a kormányzati tanulmányok szakirányú továbbképzési szak tananyagfejlesztésében, a képzésben folyó kommunikációs tréningek lebonyolításában, a közszolgálati kommunikációról, a szóbeli kommunikációról, a rendvédelmi kommunikációról szóló tankönyvek fejlesztésében. Jelentős eredmény, hogy 2017-ben lezajlott az Országos Bírósági Hivatal Magyar Igazságügyi Akadémiáján a teljes magyar bírói kar számára kötelező tréningsorozat, amelynek a célja a közérthető bírósági kommunikációhoz való hozzájárulás volt. E képzéssorozatban és az azt előkészítő tanácskozásban a MANYSI-nak jelentős szerepe volt, mint ahogy a terület szaknyelvét, kommunikációs problémáit feltáró szakértői tanácskozások lebonyolításában is. Tehát a kötet kapcsolódó fejezete mellett a MANYSI, valamint a többi intézet, kutatócsoport által felhalmozott ismeretanyag kellő alapot ad a közigazgatásra jellemző kommunikációs problémák megoldására irányuló stratégia megalkotására.

SZABÓMIHÁLY GIZELLA elemzése fontos gondolattal indít, amely megalapozza a terület fontosságát, megkerülhetetlenségét: a kisebbségi nyelvek fennmaradásának egyik záloga, hogy ne szoruljanak vissza a familiáris közegbe; pozíciói megmaradjanak, erösödjenek a nyilvános, hivatalos színtereken is (299). Mivel ezt a nyelvhasználati színteret az állam szabályozza, a területet nyelvészeknek, jogászoknak, közigazgatási szakembereknek együttmúködve kell vizsgálniuk.

Igen fontos kijelentés, hogy a környező országokban a nemzetközi és uniós szabályozásokon alapuló helyi jogszabályok hiányosak, ráadásul végrehajtásuk is akadozik. Ez feladatot ad a nyelvstratégiának, de a diplomáciának is. 
A szerző elemzi azt is, hogy milyen tényezők gátolják a hivatali nyelvhasználatot, és hogy erre miként reagálnak a helyi magyar közösségek. Közös pont, hogy a környező országok gyakorlatában a magyar nyelv föként a helyi közigazgatásban, és ott is leginkább az élőbeszédben használatos. A fordítások megszervezése, finanszírozása nehézkes, ezért az írásos hivatalos szövegek minősége nem mindig megfelelő. Általános gátló tényezőként említi SzABÓMIHÁLY GIZELLA, hogy az ügyfelek vagy nem ismerik (nyelvi) jogaikat, vagy félnek az alkalmazásuktól, de rontja a helyzetet az is, hogy nem jellemző a határainkon túli területeken az egységes magyar nyelvü közigazgatási terminológia, valamint a szakkifejezések ismeretében is hiányosság mutatkozik.

A hazai közigazgatási szövegekre is érvényes a BENÖ ATTILÁtól és PÉNTEK JÁNOStól vett idézet: „első és legfontosabb szempontunk az volt, hogy a nyomtatványokat minél könnyebben megértsék azok, akik használni fogják öket” (317). Határainkon belül nem a nyelvi kontaktushatások és a közigazgatási rendszerek különböző felépítéséböl (ez egy országon belül értelmezhetetlen is) származnak a megértési problémák, hanem főként a szerkezetek, a mondatszerkezetek felépítéséből, a rövidítésekből, a laikusoknak sokszor zavaros és követhetetlen hivatkozásokból, a logikátlan időkifejezésekből, a redundanciából, a túlzott, nehezen követhető nominális mondatszerkezetekből. Képzésre, a terminológiai leírások, egységesítések megteremtésére, a szaknyelvi terminológia egységes stratégiájának a kialakítására van szükség a határon túli régiókban. Hozzátesszük, hogy erre hazánkban is szükség van, sok egyéb más tényezővel együtt. E célból kötött a MANYSI együttmüködési megállapodásokat többek között a Termini Kutatóhálózattal és az Országos Fordító és Fordításhitelesítő Irodával, ezért dolgozott ki terminológiastratégiát a Károli Gáspár Református Egyetemmel közösen.

A számítógép, az elektronikus kommunikáció és az internet hatá s a címü fejezet szerzője PrószÉKY GÁBOR. A fejezet három olyan területet tekint át, amely jól lefedi az infokommunikációs technológia írásbeliségre gyakorolt hatását. Azért csak az írásbeliségre, mert a számítógépes kultúra esetében lényegesen erősebb az írásbeliségre, mint a szóbeliségre gyakorolt hatás (321). A magyar nyelv - mint minden nyelv - a számítógépes kultúra hatására nyilván változott, és legföképpen az írásbeliségben tükröződnek ezek a nyelvi jelenségek. Fontos észrevétel, hogy a számítógépes kultúra írott nyelvre gyakorolt hatásának vizsgálatakor azokra a szövegekre kell koncentrálni, amelyek az internetes kommunikáció tipikus, jellemzően nagy interaktivitási fokú és a személyesség irányába hajló formáiban jönnek létre. PRÓsZÉKY bemutat olyan kutatási eredményeket is, amelyek a beszéltnyelviség jellemzőit követő internetes írásbeliség számítógépes környezetből való kilépését bizonyítják. Megemlíti ennek a sajátos, internetes írásbeliségnek azt a jellemzőjét is, amely a szövegek szerkezeti módosulásaiban figyelhető meg (az interaktivitás sebessége miatt a diskurzusok egymásutániságának a megbomlása, az utólagos beszúrások miatti ismétlődések, kihagyások, szerkesztési hibák). Nyelvstratégiai szempontból is fontos figyelmeztetés, hogy ezekről a hatásokról, jelenségekről az oktatás jellemzően nem tud, és nem is léteznek rá problémamegoldási technikák. A MANYSI éppen ezeknek a problémáknak a feltárására és a közigazgatás számára való felmutatá- 
sára szervezte meg a Digitális tananyag, digitális írásbeliség címü konferenciáját, amelynek a folytatása, összegzése alapján az oktatásra vonatkozó stratégia kidolgozása megkezdődhet.

Szó esik arról is, hogy a nyilvánosságnak szánt, professzionális és nem profeszszionális szövegek színvonalát a hálózati kommunikáció felületein ma már jellemzően senki sem felügyeli, korrigálja. Rövidül a szövegek előkészítő fázisa, a korrigálási fázis pedig vagy szintúgy rövidül, vagy teljesen elmarad. A szöveg-elöállító számítógépes és infokommunikációs eszközök nyelvi segédeszközeinek a kezeléséhez is kell nyelvi, helyesírási, grammatikai tudás, nem lehet minden automatikus javítási ajánlást kritika nélkül elfogadni. A MANYSI is érzékeli ezt a problémát, és az online és a hagyományos sajtó képviselőivel olyan szakmai egyeztetési sorozaton van túl, amely nemcsak a helyzetet tárta fel a szakmai résztvevők szereplésével, hanem kellő alapot adott a területre vonatkozó cselekvési terv kidolgozására.

Mindezek a jelenségek könnyen hozzájárulhatnak az írásbeliséghez füzött általános normatíváink változásához, hiszen a fejezet szerzője szerint nagyon sokan csak internetes szövegeket olvasnak, így a fenti szövegmódosulások az olvasáson keresztül egyesek számára „,spontán normának” minősülnek (324).

PRÓSZÉKY GÁBOR állítása igen hangsúlyos, és mindenképpen cselekvésre indít: azt állítja ugyanis a fejezetben következetesen levezetett összefüggések és példák alapján, hogy a nagy nemzetközi cégek által kifejlesztett számítógépes szöveg-elóállító eszközök nagyobb hatást gyakoroltak a magyar írásbeliségre, mint a Magyar Tudományos Akadémia (326). Ebben a helyzetben cselekedni kell: ki kell alakítani azokat az oktatási, módszertani, technológiai és intézményes kereteket, amelyek a fejezetben jelzett problémákra megoldást kínálnak. Ez pedig a tananyagtervezés, a pedagógusképzés, a módszertan megújítása révén valósulhat meg: a MANYSI ennek az összetett, sok közigazgatási egyeztetést kívánó folyamatnak a fontos szereplője, ám a feladat összetettsége miatt a változás viszonylag lassú, nem várható egyik napról a másikra látványos eredmény.

A magyarországi magyar anyanyelvoktatás, az anyanyelv-pedagógi a helyzete a közoktatásban fejezet szerzője KUGLER NÓRA. Az oktatás, különösen a közoktatás az anyanyelvüség jelenét és közeljövőjét kapcsolja össze, befolyásolja, sőt nagyban meg is határozza, különösen az utóbbit. A közeljövő felnőttjei ugyanis olyan anyanyelvi, anyanyelvhasználati kompetenciát hoznak az iskolából, amely megalapozza felnőttkoruk kommunikációját, önreflexióját, ön- és közösségépítését. Ez mindig is így volt. Ezért van kiemelt jelentősége az alfejezetnek, amely az elmúlt évtizedek és a jelen anyanyelvoktatási helyzetképét írja le, és végül kijelöli a leginkább fejlesztendő területet.

A közoktatási „,szintézis” elméletileg ugyanazon az alapon áll, mint amelyet a kötet bevezetőjében a szerkesztő vázolt, tehát elsősorban kognitív-funkcionális alapú. A kérdések, amelyekkel foglalkozik, bevallottan sem terjednek ki az anyanyelvi közoktatás egészére. Mivel a terület nagyon összetett, ez természetes is. Mégis hiányzik, különösen a kognitív-funkcionális szemléletet feltételezve, hogy említésen kívül nem kapunk mást, mint például egy összefoglalót a (bármely okból) speciális igényü tanulók anyanyelvoktatási lehetőségeiről, oktatásuk-nevelésük szakszerüségének fontosságáról. Hiányzik például az is, hogy az alfejezet 
legutolsó mondata kivételével szó sem esik a kívánatosnak bemutatott oktatási rendszerben a pedagógusképzésben szükséges változásokról: hogy olyan, jelen esetben magyar nyelv és irodalom szakos pedagógusokat képezzünk, akik nem egyetlen merev felfogást ismernek, hanem olyan szaktudományos látásmódot sajátítanak el, amely munkájuk során segíti majd öket a közben megszülető tudományos eredmények integrálásában is, amely nyelvészetileg alapozza meg a problémalátás és -megoldás módszertanát, a nyelvi rendszer és a nyelvhasználat elvárható harmóniáját. A szükséges tananyagbeli és módszerbeli változtatások a magas szintủ pedagógusképzés és a folytonos továbbképzés nélkül nem állhatnak meg. Hiányzik még a fejezetnek az a szélesebb látóköre, amely az anyanyelvet nemcsak mint az anyanyelvi óra tárgyát, hanem mint közlési közegét is tekinti, és nem csupán a magyar nyelvi órákon, hanem minden egyéb szakórán és müveltségterületen. Ez utóbbinak a kulcsa megint a pedagógusképzésben keresendő: a megfelelö tematikájú és színvonalú anyanyelvi blokkok beépítésében, bármely szak pedagógusképzésében, éspedig megfelelő, célszerủ tematikával. Hiánynak tekinthetjük azt is, hogy nem beszél a fejezet a felsőoktatás anyanyelvi elvontfogalom-alkotásának fontosságáról sem.

Ami nem hiányzik a szintézisből, az arányos, lényeglátó és következetes. A magyarországi magyar anyanyelv-pedagógiát tekinti át a közoktatási, bár inkább a felsőbb osztályokbeli színtereken (az óvoda és az alsó tagozat kimarad). Elöször magával a tantárggyal foglalkozik: a tantervek jellegével, megújulásával, a magyar nyelvnek az elmúlt évtizedek tanterveiben elfoglalt szaktárgyi helyével, a kerettanterveknek néha inkább korlátozó, mint lehetőséget adó szerepével, a tananyag „,modernizációjának” kísérleti, töredékes vagy eklektikus voltával.

A kétszintü érettségi lehetőségei, előnyei között felsorolja a szerző azt a hatást, amelyet az emelt szintü követelmények visszahatásként a tanórákra tesznek. Fontos azonban, hogy a bármilyen természetú új követelmények a szemlélet megváltozásával járjanak, és ne valamilyen mechanikus begyakoroltatással. „Az ismeretekre vonatkozóan szabályalapú, a nyelvet a beszélőktől függetleníthető tárgyként tételező nyelvértelmezés és az erre épülő nyelvtantanítás elidegeníti a nyelvet a beszélötől, a diáktól. Az oktatási környezet, a lassan változó tanórai interakció-típusok, munkamódszerek [...] és más tényezők mellett részben ennek az elidegenítő hatásnak, a nyelv tárgyiasításának a következménye az a tény, hogy a diákok nem szeretik a nyelvtant, a tantárgynak alacsony presztízst tulajdonítanak, és nem is teljesítenek jól sem a nyelvtanórán, sem a magyar [...], sem a nemzetközi méréseken" (342, hivatkozásokkal). Hogy ez jelentős probléma, az nem kétséges, viszont megoldása összetett folyamat, amely a MANYSI véleménye szerint a tanárképzésnél kezdődik, a módszertani megújuláson át a tantervalkotásig, a tananyagfejlesztésig tart - a stratégiaalkotás során tehát minderre figyelemmel kell lenni.

Az áttekintés foglalkozik a tankönyvekkel is (konkrétan: ANTALNÉ SZABÓ ÁGNES - RAÁTZ JUDIT: Magyar nyelv és kommunikáció; valamint a kísérleti, illetve az ún. újgenerációs tankönyvek). Mindkettőből hiányolja a szerző (bár különböző mértékben) azoknak az elvárásoknak való megfelelést, amelyeket korábban a tananyaggal és a módszertannal kapcsolatban megfogalmazott. És hiányolja a tankönyvkutatásokat is, inkább csak a támogatott, nagyobb projektekkel számol, holott kisebb 
kutatócsoportok jelentős - empirikus kutatáson alapuló - eredményeket mutatnak fel. És ha már a tankönyvszöveg-elemzés szükségességét hangsúlyozza a szerző, szerintünk nem lenne szabad megállnia az anyanyelvi tankönyveknél, hiszen a többi közismereti terület tankönyvei is magyar szövegüek. A tanóra-kutatási eredményeknek is csak egy része anyanyelv-módszertani vonatkozású, a többi általános, tehát több tantárgyra is érvényes módszertani következtetésekre adna alkalmat.

A határon túli magyar tannyelvü és magyar tematikájú k ö z o k ta tá s fejezet szerzője közel 70 oldalon mutatja be a határon túli oktatás helyzetét és problematikáját, ami több okkal is magyarázható: a) a magyar nyelvközösség számottevő része él kisebbségi helyzetben, s anyanyelvüségük veszélyeztetettsége miatt okkal kerülnek a figyelem középpontjába; b) az anyanyelvoktatás kisebbségi helyzetben több nehézséggel küzd, mint többségi helyzetben; c) a kisebbségi anyanyelvoktatás mint nyelvstratégiailag talán legfontosabb terület rendelkezik a leginkább stratégiai irányultságú tudományos leírásokkal.

Az általában igaz a Kárpát-medencei magyar közösségekre, hogy identitásuk egyik legfontosabb eleme az anyanyelv, ennek a megtartásában pedig a legmeghatározóbb szerepe az anyanyelvủ oktatásnak van. A kisebbségi helyzetúek oktatása már magában is nehezebb, mint a többségi helyzetben levőké. Kétnyelvü környezetben élnek, nyelvi helyzetük a kétnyelvüség. Ennek a milyensége és fokozatai pedig meghatározzák azt, hogy mi felé tartanak: az anyanyelv megtartása vagy a nyelvcsere felé. Tömbben inkább hozzáadó (additív), szórványban azonban inkább felcserélő (szubtraktív) ez a kétnyelvüség. Fontos kérdés tehát a kétnyelvüsödés mikéntje. Az államnyelv elsajátítására szükség van ugyan, de az államnyelvi iskolázás valószínüleg szubtraktív kétnyelvüséghez vezet, hiszen „Ha az egyén által tökéletesen elsajátított második nyelv lesz az egyén domináns nyelve, a saját kisebbségtől való elidegenedés, gyökértelenné válás esélye megnő" (359).

A hét Kárpát-medencei kisebbségi magyar terület oktatási sajátságait különkülön mutatja be a szerző. Adatai a lehető legfrissebbek, a népszámlálási adatok és az oktatásra vonatkozó jogszabályok, statisztikák is (ez utóbbiak a legtöbbször a 2015/16-os évvel zárulnak). Az egyes régiók bemutatása azonos szempontok szerint történik: népességi arányok, területi megoszlás (és különbségek), az oktatás jogi keretei: törvények, oktatási szervezetek (központiak és kisebbségiek), iskolarendszer, iskolahálózat, iskolatípusok (az oktatás nyelve szerint). Az iskola előtti és az érettségi utáni oktatási lehetőségek általában inkább csak említés szintjén kerülnek elő, az ezek közötti iskolai szerkezetet azonban részletesen tárgyalja a szerző, mégpedig tartalmilag is, de csak a magyar nyelv tantárgy tekintetében, általában a következő szempontok szerint: a) a magyar nyelv oktatásának szervezeti és tartalmi keretei; b) tantervek, tankönyvek. A beszámolók részletességükben általában a magyar kisebbség lélekszámával arányosak, de van kivétel (a szlovákiai kisebbségi oktatás leírása talán éppen a szerző „helyismerete” miatt bővebb is, differenciáltabb is a többiénél).

A régiókban különböző mértékben merülnek fel olyan problémák, mint a népességfogyás, az elavult magyar nyelvü tankönyvek, a többség nyelvén íródott tankönyvek magyarra fordításából származó problémák, a korlátozó érvényü törvények és egyéb szabályozások; ezek mellett sok más egyéb jelenséget tárgyal 
a szerző régiónkénti bontásban, alapos részletezettségben. Csak az ukrajnai magyar kisebbségről szóló részből emelünk ki néhány változást. A magyarok lélekszáma itt is csökken, az itteni kisebbség azonban a legszervezettebbek közé tartozik. A kisebbségi anyanyelvü és anyanyelvi oktatást azonban a törvényi háttér, különösen a legutóbbi oktatási kerettörvény (2017. szeptember) erösen korlátozza: nincs a kisebbségnek joga a teljesen magyar nyelvü oktatáshoz. Ez diszkriminatív (a krími tatárok tanulhatnak anyanyelvükön), és sérti Ukrajna alkotmányát is.

Összefoglalva: az ismertetett oktatási rendszerek többsége folyamatosan változik, $\mathrm{s}$ ez csökkenti az érintettek biztonságérzetét; a változások iránya ráadásul inkább negatív, mint pozitív. A fejezet egésze korrekt összefoglalása a határon túli magyaroktatás helyzetének. Sajnos azonban a részfejezet végéig nem derült ki, mit is jelent a címben szereplő „magyar tematikájú oktatás”.

V. A magyar nyelv és az irodalom (KULCSÁR SZABÓ ERNŐ). A fejezet a magyar nyelvi tervezés, a nyelvstratégia számára nem tartalmaz sok információt. Leginkább történeti szempontú nyelv- (illetve inkább irodalom)filozófiai, hermeneutikai áttekintést kapunk, a gyakorlati oldal pedig hiányzik.

Ezt azért tartjuk nagy problémának, mert az irodalom gyakorlati, nyelvi tervezési megközelítésére egyértelműen szükség van, hiszen a nyelv - ahogyan a szerző is megállapítja - nem pusztán eszköz, és nem pusztán anyaga az irodalomnak, hanem az irodalom az írott (?) nyelv(i kifejezés) emelkedettebb foka, művészete. Sok tanulság és tennivaló kínálkozik ezen a területen is, de ezeket -az irodalomnak az identitásalakításban és a nemzeteszmény formálásában betöltött szerepe, az olvasásszociológiai vetületek, az irodalomoktatás Magyarországon és a határon túl, az irodalom és a magyar nyelv tantárgyának egymáshoz való viszonya, a fordításirodalom és annak ösztönzése stb. - a fejezet nem tárja fel.

VI. A magyar nyelv külföldön (NÁDOR ORSOLYA). A címben megjelölt témánál többet kapunk a fejezetben, hiszen a nyelvünk külföldi presztízsének megtartására vagy növelésére irányuló törekvés mellett olvashatunk a nyugati szórványmagyarságról, az őket érintő magyaroktatásról is.

„A nyelvek megmaradásának egyik záloga az, hogy a nyelvközösségen kívül is ismert[ek] legyen[ek]" (465). A magyar nyelv és kultúra külföldi megismertetése tulajdonképpen „kultúrdiplomáciai” feladat, a szónak nemcsak a szoros értelmében. Ma külföldön évente legalább 2000 nyelvtanulóval számolhatunk, s a létszám évtizedek óta változatlan, a kisebb ingadozások ellenére is. Az utóbbi időben megnőtt például Ukrajnában a magyart idegen nyelvként tanulók létszáma, ugyanakkor éppen Ukrajnában született meg a magyar kisebbséget hátrányosan érintő oktatási törvény.

Intézményi háttere is van mindennek Magyarországon és külföldön is: idehaza a Debreceni Nyári Egyetem 1927 óta, az ELTE Magyar mint Idegen Nyelvi Tanszéke és jogelődje 1952 óta, a Balassi Intézet és jogelődje 1957 óta. A külföldi intézmények egy része nagy múlttal büszkélkedhet, nagyobb részük egyetemi oktatóhely, más részük Collegium Hungaricum. Ez utóbbiak ma is müködnek, és bár nem a magyar nyelv oktatóhelyei, hanem hungarológiai kutatóközpontok, 
mindenképpen nyelvünk és kultúránk külföldi jelenlétét szolgálják. A külföldi hungarológiai felsőoktatási központok általában Magyarország kezdeményezésére jöttek létre, és az is általános, hogy Magyarország nagyrészt saját költségére küld ki oktatókat: lektorokat és vendégtanárokat. Ezeknek az oktatóhelyeknek a mai helyzete azonban sokszor bizonytalan. Ebben pedig nemcsak szervezési és esetleges anyagi hiányosságok játszanak szerepet, hanem az is, hogy a bolognai rendszer bevezetésével sokkal inkább gyakorlati igényeket kezdtek támasztani a hallgatók az egyes nyelvszakokkal szemben, mint korábban. A filológiaközpontú magyar szakos oktatás erre azonban nincs felkészülve, s olyan motivációs ereje sincs nyelvünknek a világban, hogy megakadályozhatná az érdeklődés megcsappanását; így folyamatosan csökken a hallgatók létszáma. A MANYSI meggyőződése, hogy a magyar nyelv külföldi oktatását előrelendítheti egy olyan online tananyag kifejlesztése, amely központi forrásból, egységes módszertannal, minden tudásszinten elérhető az érdeklődők számára, ehhez azonban szükséges a politikai döntés, a fejlesztés gazdájának a kijelölése, a folyamat végigvitele, emellett pedig ki kell képezni azokat a tanárokat, akik ismerik a digitális, távoktatási módszereket.

Az emigráltak és utódaik anyanyelvének, majd később származásnyelvének oktatása nem lehet iskolarendszerü, hiszen általában szórványban élnek. A célország magyar közösségei teremtik meg a magyarnyelv-oktatás lehetőségeit, leginkább hétvégi iskola formájában. Ennek az oktatásnak legfőbb jellemzői, hogy nem szakképzett tanárok tartják az órákat, és nincsenek megfelelő színvonalú speciális tankönyvek a származásnyelvüket tanuló diákok számára. Ezeknek az oktatási helyeknek a tankönyvellátása, támogatása mindenképpen központi feladat, és a mind nagyobb számban elérhető digitális, online tananyagok igénybevételével is életben lehet tartani ezeket a mühelyeket. Ehhez viszont meg kell ismerni ezeket a hétvégi iskolákat, rendszeresen kommunikálni kell velük, és anyagi forrást kell találni működésük fenntartására.

VII. Nyelvi tervezés (TOLCSVAI NAGY GÁBOR). A nyelvstratégia-alkotás iránt érdeklődő vagy a stratégiaalkotásban érdekelt olvasónak ez a fejezet a leginkább érdekfeszító, a leghasznosabb, természetesen a bevezető elméleti fejezettel együtt. Az eddig megjelent stratégiák vagy stratégiai javaslatok közös jellemzője ugyanis - a különbségektől és a minőségtől most eltekintve -, hogy nem tudták elgondolásaikat közös elméleti alapra helyezni, és az egyes jelenségeket erről az alapról szemlélni, tárgyalni. Voltaképpen csak a keretfejezetek szerzőjének munkáiban találkozhatunk folyamatosan - immár évtizedek óta - azzal a szemlélettel, amely a nyelvre és a közösségre úgy tekint, mint két egymást és önmagát is folyamatosan (újra)alkotó létezőre.

A cél eléréséről (a nyelv fenntartása és jövőbeli léte irányának kijelölése), illetőleg az ahhoz elvezető stratégia kidolgozásának esélyeiről és lehetőségeiről a szerző bizakodóan nyilatkozik. Úgy látja, hogy a nyelvközösség és a nyelv önmagát létrehozó folyamatában a hagyomány müködtetésével, átalakításával és a jövő megnyitásával egy autopoietikus ,nyelvstratégiának a kifejtésére [...] és kidolgozására minden esély megvan ma is" (488). Konszenzus, tudományos ala- 
pozás, alkotó gyakorlat és felelős tervezés - ezek a kulcsfogalmak és elvárások a stratégia kidolgozásában.

A kötet az elvi alapozáshoz híven a funkcionális megközelítést tartja célravezetőnek a stratégia megalkotásában: a nyelv rendszer jellegét, használatát és közösségi, kulturális tényezőit egyaránt egységben kell szemlélnünk a modellalkotás és a tervezés során is. A nyelvi rendszer működése a sémák különféle hüségü ismétlését, reprodukálását jelenti, és a nyelvi gyakorlat és visszacsatolás kapcsolata szerint két szinten valósulhat meg (elemi, átlagos és minőségi, alkotó szinten); ebben az összefüggésben szemlélve minden lényeges tényező és szereplő összekapcsolható, és a helyesség is - az adekvátság magasabb rendủ kategóriája alá kerülve - elnyeri megfelelő értelmezését.

A legfontosabb nyelvtervezési feladatoknak a következőket tartja a szerző: a nyelvi hiányok megszüntetése korpusztervezéssel, korpusz- és státustervezés a jövőbeli standard nyelvváltozattal kapcsolatban, a nyelvi tanácsadás rendszere, a határtalanítás kiterjesztése részkérdésekre, az idegen szavak kettős viszonyának és az egységes terminológiáknak a kidolgozása, a digitális nyelvhasználat segítése. Emellett a MANYSI fontos területnek tartja egyebek mellett a közigazgatás közérthető kommunikációjának elősegítését, a média nyelvhasználatáról való stratégiaalkotást és az oktatással kapcsolatos nyelvstratégiát is.

A szerző a nyelvstratégia részeként tartja számon a nyelvpolitikát, a nyelvvel kapcsolatos politikai döntések rendszerét. Ennek tükröződése lenne a jogi keret, amelyet a nyelvvel kapcsolatos szabályok összessége alkotna. Ez az illeszkedés nálunk ma még nincs meg, pedig szükség lenne arra, hogy a tudományosan leírt tények és a jogszabályok illeszkedjenek egymáshoz, valamint hogy érintsenek eddig nem szabályozott területeket is (például a nyelvváltozatok státusa, különösen a közösségi nyelvi jogok elismertetése, a hátrányos helyzetüek kisebbségi nyelveinek státusa).

Az oktatás, kiemelten az anyanyelvi oktatás és nevelés szerepe a nyelvstratégiában alapvető szerepet játszik. Az elérendő célok: a nyelv és a nyelvhasználat egysége, a nyelv variabilitásának oktatása, a nyelv funkcióira építő oktatás, a kisebbségi magyaroktatásban az anyanyelv legyen az első nyelv, tartsák meg az iskolai nyelvtanórákat. Kérdés, hogy az általános kultúrpolitika hogyan viszonyul ezekhez a célokhoz. A mai helyzet ebből a szempontból nemcsak összetett, hanem ellentmondásos is.

A fô célok összefoglalásával, magasabb szintre emelésével együtt a kételyek, kérdések és alapvető veszélyek is előkerülnek, s egyes ideologikus, egyoldalú nézetekről is újra szó esik: a szerző a szélsőségek, az egyoldalú és tudománytalan nézőpontok veszélyeire hívja föl a figyelmet, utalva a történelmi hiedelmekre is. Ezen a ponton a gyökelmélet vagy a hun-magyar rokonság (a rokonság szó idézöjelben szerepel) hirdetését, politikai ideológiára épített iskolai terjesztését említi riasztó példaként. Az alapállítással egyetértünk: az ideológiák oktatásban való reflektálatlan, hallgatólagos vagy evidenciaszerü jelenlétének, használatának megkérdőjelezését jogosnak tartjuk. A gyökelméletnek és a hun-magyar rokonságnak a művelt, nem szakmai köztudatban való létezését azonban nem tagadhatjuk. Ép- 
pen ezért véleményünk szerint a nyelvtudománynak nem szükséges elvetnie az ezekkel a kérdésekkel való tárgyilagos és árnyalt foglalkozást.

Az ígért szintézis, valamint a staféta továbbadása a politika és a közigazgatás számára - cselekvési terv, stratégia kimunkálása céljából - mindenképpen megkívánná, hogy folytatódjék a kötetben bemutatott területek további részletezése és tudományos feldolgozása. Joggal merül fel az olvasóban, hogy kívánatos lenne a tudományos véleménynyilvánításnak és a gyakorlati, közéleti, politikai cselekvésnek, szerepvállalásnak az összekapcsolódása. Szerencsére ez ebben a szintézisben a lehetőségek keretein belül megtörtént - hiszen a tudomány itt olyan mértékben közelített a gyakorlathoz, amely eddig példátlan volt. A felelösség és feladatvállalás másik része, valamint a müködtetés már a stratégiaalkotókon, a politikai akaraton és a megvalósítókon múlik. Egyetérthetünk a szerkesztőnek a tudomány, a politika és a mindennapi nyelvi gyakorlat hármasára vonatkozóan tett figyelemfelhívó és biztató megállapításával: „Össze lehet-e egyeztetni e három tényezőt? Nem ez a kérdés, hanem az, hogy miképp lehet őket összehangolni. A viszonylagos összhang nélkül nem lesz eredmény. A nyelvstratégia tervezőinek ez az egyik legfontosabb feladatuk" (503).

A mai magyarországi nyelvhasználatot elsősorban dicséri és méltatja a szerkesztő. A megtartóerő, a termékenység, a versenyképesség és a teljesítőképesség, az alkotás, a kreativitás öröme, az identitás büszkesége, a változatosságban az egésznek s az egészben a változatosságnak a keresése és megtalálása, ennek öröme szintén üdvözlendő, és megnyugtató kicsengést is ad e fejezetnek. Megjegyezzük azonban, hogy az árnyoldalakra és a nyugtalanító jelenségekre is határozottan fel kellene hívni a figyelmet, mert enélkül hamis képet, torz helyzetértékelést kapunk a mai nyelvállapotról.

Fontos, jelképes zárása és üzenete a kötet stratégiában végződő utolsó részletező, elemző fejezetének, hogy a stratégia kidolgozásában és végrehajtásában részt vevő minden személynek és intézménynek a diszkurzivitás szellemében a vita, a párbeszéd és az önreflexió nélkülözhetetlenségét, állandóan újrainduló folyamatosságát fogalmazza meg felelősségként és kötelességként, afféle erkölcsi parancsként. Ha ezt minden résztvevő érvényesnek ismeri el magára nézve, a folyamat nemcsak egy életképes nyelvstratégia kimunkálásához vezethet el, hanem annak megvalósulásához, végrehajtásához és a nyelvközösség felelős csoportjainak a közmegegyezéséhez is - a nemzeti kultúráért és a közösségért felelős mindenkori kormányzat cselekvő, kezdeményező és egyetértő részvételével.

VIII. A jövő felé irányuló látókör. Összefoglalás (TOLCSVAI NAGY GÁBOR). A szerkesztő ebben a fejezetben röviden összefoglalja a kötet tartalmát, célját: a múltban szerzett tapasztalat és a jelen tudás adta a helyzetképek összességét, mindez együtt mutat anyanyelvünk jövőben várható helyzetére. Röviden utal a vizsgált korszakra, az új jelenségekre, a legfontosabb tendenciákra. A szintézis és az elméleti keret folyamatos megjelenítése és alkalmazása érdekében igyekszik tárgyilagos és kellően távlati nézőpontot választani.

Itt térünk át röviden a kötet véleményünk szerinti néhány fogyatékosságára. A konkrétság eltérő mértékủ az egyes fejezetekben: a magyar nyelvi helyzet jel- 
lemzésére szolgáló, a stratégiához szükséges nyelvhasználati jelenségek köréből többnyire csupán általánosságokat vagy ritkán egy-egy szemléltető példát kapunk; bizonyos mértékig természetes, hogy a nyelvi jelenségek gyakran bizonytalan tendenciaként, kérdező megfogalmazásban s nem teljes körüen vannak felsorolva.

A nyelvi színterek és meghatározó tényezők közül a média teljesen kimaradt. Ezzel a területtel kapcsolatban a MANYSI elvégzett szakmai munkával, kidolgozott javaslatcsomaggal rendelkezik. A nyelvi jelenségek önálló tárgyalása kimerül a köszönés- és megszólításformák kétségtelenül igen fontos és feltétlenül tárgyalandó, ám mégsem egyedüliként említést érdemlő jelenségkörében; a hazai közigazgatás, a hivatali nyelv, a politika mint közeg vagy az üzlet mint szféra sem kerül elő önállóan, pedig a reklám és az üzlet, a politika és a média, valamint a közigazgatás területe, szolgáltatásai és rendszere nélkül aligha lehet teljes a mai magyar közlésháló terepeinek, funkcióinak és szereplőinek, meghatározó tényezőinek és jelenségeinek bemutatása, leírása. Az irodalom és a nyelv címü fejezet csak szemléletmódjában mutat kapcsolatot a kötet fejezeteivel és céljával: a stratégiai tervezésbe e fejezet jelen készültségi szintjén nem épülhet be.

Bár az Előszó szerint a kötet szabatos nyelvezetü, és megértésre, megértetésre törekszik, a szöveg értelmezése nem mindig egyszerü. Természetesen vannak nyelvileg példaszerủen megírt részek is (például A magyar nyelv és a magyar nyelvközösség jogi helyzete, A népesedési viszonyok, A külső régiók vagy A számítógép, az elektronikus kommunikáció és az internet hatása címü fejezet).

A szerkesztő úgy látja, hogy nyelvközösségünk kiválóan birkózik meg a „kihívásokkal”, tehát továbbra is életképes mind kultúrájában, mind nyelvében. Kisebbségeink nyelvi jogainak korlátozása és a népességcsökkenés azonban gyöngítheti életképességét. Ezért szüksége van arra, hogy spontán önreflexióját kiegészítsék a nyelvtudomány e müködésre vonatkozó eredményei, a nyelvi tervezés hiányenyhítése, valamint hogy ,a nyelvstratégia a teljes magyar nyelvközösség számára a fennmaradás és a jó müködés általános feltételeit" rögzítse. Ilyen nyelvstratégiánk még valóban nincs, pedig a nyelvtudomány elégséges alapot nyújtana hozzá.

A könyv utolsó, a MANYSI-ra vonatkozó mondata részben elmarasztaló, de felfogható úgy is, hogy a tudományos élet egy hiteles rétege nemcsak várja és támogatja a nyelvstratégiát, de el is ismeri, hogy annak elkészitése, későbbi felügyelete a MANYSI hatáskörébe tartozik, s ehhez támogatást és segítséget ígérnének a kötet szerzői. Az egész kötet ívének jelképes záróakkordja a magyar nyelvstratégia iránti várakozás megfogalmazása, $\mathrm{s}$ a feladat továbbadása a MANYSI-nak. Meglátásunk szerint némi csalódottság bujkál a megfogalmazásban, ezt talán érdemes ösztönzésként, a stratégia megalkotása iránti sürgető igény kinyilvánításaként felfognunk. Azzal teljesen egyetérthetünk, hogy a magyar nyelvstratégia megalkotására szükség van, s e feladat a MANYSI feladata. Ennek elvégzéséhez a kötet gondolatébresztő és kellő elméleti alapozást vázol fel és ad közre: a legfontosabb fogalmakat és kategóriákat számba veszi, megfelelő módszert és elvi keretet nyújt.

A kötet nagy segítséget jelent egy jól megalapozott, teljességre törekvő, körültekintő, modern és hatékony, a közmegegyezést és az elfogadást is elnyerő cselekvési program, egy korszerü és végrehajtható magyar nyelvstratégia kidol- 
gozásához, a folyamatban levő nyelvstratégiai résztervek és a stratégiai tervezési munkálatok kiegészítéséhez, gazdagításához, elvi-módszerbeli és tudományos szempontú átvizsgálásához és kritikájához.

Kulcsszók: magyar nyelv, nyelvi tervezés, nyelvstratégia, anyanyelvi nevelés, nyelvközösség, nyelvhasználat, nyelvmüvelés.

\section{Reflections of the Institute for Hungarian Language Strategy on the volume 'The present and future of Hungarian'}

This paper reviews and evaluates the volume 'The present and future of Hungarian', edited by Gábor Tolcsvai Nagy, from the viewpoint of the Institute for Hungarian Language Strategy. Given that the topic of the volume is the present state of this language, as well as language planning and language strategy, the Institute obviously appreciates the scientific results presented in the volume concerning an array of fields within the general area of language use. We also reflect on those results and mention our own accomplishments in the given fields. The community of the Institute see the importance of the volume in the fact that it justifies the existence of individual language planning processes and of language strategy that collectively covers those processes both in a professional and in an administrative sense and provides help for the relevant governmental background institution, the Institute for Hungarian Language Strategy, fulfilling a linking role between the world of linguistics and that of state administration, in developing an ever more professional language strategy for this language community.

Keywords: Hungarian language, language planning, language strategy, first language education, language community, language use, language cultivation.

BÓdi ZOLTÁN, EÖRY Vilma, KATONA JÓZSEF Álmos, STRAuSz PÉTER, TÓTH ATTILA, H. TÓTH TiBOR Magyar Nyelvstratégiai Intézet 